\title{
The Behaviorist Plot
}

\section{John Staddon}

Rebecca Lemov, Professor of History of Science at Harvard and an anthropologist by training, has written a book about behavioral control: World as Laboratory (WAL). ${ }^{1}$ WAL conjures up a plot. The plotters are behaviorists, a group into which Lemov bundles every kind of psychology, from rats in mazes to Timothy Leary, from intelligence tests to the SAT, not to mention brainwashing and a vast anthropological database at Yale University. Sigmund Freud also gets a spot, as one inspiration for the Institute of Human Relations at Yale in the 1930s.

The book would hardly be worth mentioning except for the facts that (a) Lemov is at Harvard, home of B. F. Skinner's radical behaviorism, which was the most influential kind. (b) She gets almost everything wrong about Skinner and his younger colleague Richard Herrnstein; and (c) she doesn't understand the science.

As a behaviorist ${ }^{2}$ with personal experience ${ }^{3}$ of some of the things that Lemov describes, I found her version of Harvard behaviorism totally unrecognizable. She includes behavioral/human/social engineering as parts of behaviorism which, historically, they were not. She also has almost nothing to say about B. F. Skinner, citing only his first book, Behavior of Organisms (1938). Yet it was Skinner who followed most closely the prescriptions of behaviorism's founder John Broadus Watson, not Yale's Clark Hull, who was much more interested in mathematical models of rat learning than in the control of human behavior writ large. The animal-laboratory wing of behaviorism had no interest at all in the "conviction ... that the insights of Freud could be merged with the science

1 Rebecca Lemov, World as Laboratory: Mice, Mazes and Men (Hill and Wang, e-book 2011). (The behaviorists used rats and pigeons not mice, but alliteration rules.)

2 John Staddon, The New Behaviorism: Foundations of Behavioral Science, 3rd edition, (Philadelphia, PA: Psychology Press, in press).

3 John Staddon, The Englishman: Memoirs of a Psychobiologist (University of Buckingham Press, 2016).

John Staddon is a psychobiologist and James B. Duke Professor Emeritus, Department of Psychology and Neuroscience, Duke University; jers@duke.edu. He last appeared in these pages in winter 2020 with his article "What's Really Wrong with America." 
of behaviorism.” Skinner's radical behaviorism (wrongly labeled "operant conditioning," which is a procedure not a philosophy) was indeed concerned with control. Skinner himself wrote about his ideas for society in several books and articles, most notably Beyond Freedom and Dignity (1971) and his novel Walden II. On the other hand, Lemov links behaviorism-which, at least as far as the theoretically oriented Hullians were concerned, was little interested in immediate human application-to a number of bad practices such as brainwashing, encouraged by the U.S. government and abetted by various foundations. I'm aware of no such connection to Skinner or even Hull.

Lemov sometimes misses the point. The large anthropological database, named the Human Relations Area Files in 1948 at Yale, was to be used for "statistical and correlational methods of scientific enquiry." Lemov admits that the desire for a kind of natural history of cultures is reasonable and dates from the nineteenth century. Just as the "botanizing" of birdwatchers and beetle collectors provided the database that allowed Linnaeus to classify and Darwin to understand the evolution of animals, so a database of cultures is a reasonable beginning for the science of man. Nevertheless, Lemov finds this endeavor to be hubristic if not sinister, because "[the data were] easily transformed by the impetus of World War II into an intelligence source and collator, an administrative device for tracking displaced or interned people, an aid to military occupation, and eventually a cold war strategy tool to use in locations at home and far from home." Should knives be abolished because they can be used to cut people? That seems to be Lemov's logic.

The organizing theme for WAL is the control of human behavior, although Lemov puts it very un-behavioristically as being able to "quantify and control the internal arena of the personal self," whatever that is. She doesn't like the idea of scientifically controlling behavior, even though "the running of a modern society would [then] require less brute external force. . . putting this idea into practice would make it possible to regulate human beings in tune with the needs, demands, desires, and models of the social order." The problem seems to be that the method "leav[es] no room for what sentimentalists would call the soul." What she is really objecting to is "the general idea of a science of human behavior [that] had bewitched people for a long time.”

In other words, what we seem to have here is a historian of science who rejects the very idea of a science of human behavior. Lemov seems to object to 
three things: 1 . that behaviorists are cruel to animals, 2 . that they want to control behavior, and 3. that they view organisms as machines.

Let's take these one by one. How cruel are behaviorists? In fact most Skinnerian behaviorists do single-subject experiments that are never invasive and rarely painful, the animals are hungry, but no more than they would be in the wild, and they re-use the same animal repeatedly. These experiments are much less cruel to many fewer animals than the majority of animal studies in biomedicine. Medical pioneers like Vesalius and Pasteur were a great deal tougher on animals than any behaviorist.

To point 2, Lemov traces the idea of control to the originator of behaviorism John Broadus Watson (1878-1958), who famously wrote: “Psychology as the behaviorist views it is a purely objective experimental branch of natural science. Its theoretical goal is the prediction and control of behavior." True, science often ends up with methods for controlling nature. But knowledge is the true aim of science, not control. In Richard Feynman's memorable words: "Science is a lot like sex. Sometimes something useful comes of it, but that's not the reason we're doing it." Watsonian behaviorists were indeed over-eager for control. Lemov is right to be cautious.

To point 3, the organism-as-machine: the book reviews some of the searches for mechanism in biology, beginning with Jacques Loeb (1859-1924), who is famous in psychology for his studies of simple orienting mechanisms in plants and lower organisms. Loeb was committed to the idea of animals as machines, to an "engineering standpoint," as WAL puts it. Lemov is not a fan, even though a belief in the lawfulness of the biochemistry underlying life was essential to the development of molecular biology. Conversely, a science of the soul, consciousness or indeed of anything that cannot be measured objectively, is almost certainly a lost cause. Yet that seems to be the path that Lemov favors.

Lemov rejects the fundamental tenets of behaviorism even as she insists that modern society actually lives by them: "the science of behaviorism was made to factor out such things as emotional states, innerness, subjectivity, and the unconscious and reduce activity to a series of blind mechanisms." First, "blind mechanism" is surely just a pejorative way of saying that science, all science not just behavioral science, must begin with the assumption that its subject matter is lawful, deterministic. Second, “innerness," “subjectivity,” and the like are part of behaviorism to the extent they can be observed by third parties. I cannot know the "innerness" and "subjectivity" prompted in Lemov 
by the Mona Lisa, but I can see if she judges the Leonardo more similar to $L a$ Bella Principessa than to Picasso's Weeping Woman. That is all that behaviorism means now ${ }^{4}$ and it is accepted by most of behavioral science. ${ }^{5}$ Moreover, many behaviorists, including (surprisingly) B. F. Skinner, acknowledge the reality of an unconscious, ${ }^{6}$ if not Freud's version. And third, Prof. Lemov and I remain perfectly free to experience as much "innerness" and "subjectivity" as we like: life is not science.

The main problem with the book is that it forgoes accuracy in favor of an intriguing political narrative: that modern capitalist society is run like a lab experiment propelled by billions of dollars funneled into laboratories that were engineering behavioristic methods of social control. In service of this story, Lemov seriously distorts the history of behavioristic psychology. She places much emphasis on Clark Hull (1884-1952) at Yale, calling his research program in search of quantitative principles of learning "ridiculous." Hull and his followers found a few things and failed in many respects. But science is trial-and-error; failure is an essential part of it. Lemov's failure to understand that basic fact suggests that she really does not understand what some call "the spirit of science."

Clark Hull was influential, but the context is missing. Hull was not the most important behaviorist and the line of work he started led not so much to behavioral engineering as to cognitive psychology, helped along the way by the U. C. Berkeley “purposive behaviorist” Edward Chace Tolman (1886-1959), who once claimed that everything about human psychology could be learned from the behavior of a rat at a choice point.

The context is a field called experimental psychology, represented at Harvard in the 1950s and early 1960s by the Department of Psychology, which was housed in the basement of Memorial Hall with just a half dozen faculty. The rest of psychology was in the much larger Department of Social Relations in Emerson Hall. Experimental psychology was inspired by nineteenth century German psychologists interested in sensation perception and memory; in the U.S. and U.K, the study of learning soon became a major component. A grand survey of the field is Charles Osgood's massive 1953 Method and Theory in Experimental Psychology; its history is covered in two books by Harvard psychologist Edwin G. Boring

\footnotetext{
4 See, for example, the discussion of the color-phi phenomenon in Staddon, op. cit., Chapter 18.

5 Henry Roediger, "What happened to behaviorism," APS Observer, March 1, 2004.

6 John Staddon, "Theoretical behaviorism," Behavior and Philosophy 45 (2017): 27-44.
} 
(neither cited in WAL). ${ }^{7}$ Experimental psychology no longer exists as a separate entity. Following a national trend, the two Harvard departments were merged into a single Department of Psychology in 1972, housed in the multi-story William James Hall (where Lemov apparently now resides).

The two dominant behavioristic movements were headed by Clark Hull at Yale with his younger colleague Kenneth Spence at the University of Iowa, and B. F. Skinner and friend and fellow Harvard student Fred Keller at Columbia. It was Skinner who most closely followed Watson's lead, working with rats and later pigeons as experimental subjects. (Bizarrely, Lemov has Skinner “doing his dissertation on tropism in ants" - she cites his 1938 book, which is based on his dissertation, but has evidently never read it.) ${ }^{8}$ Skinner, who is mentioned mostly in asides in Lemov's book, was indeed interested in the control of behavior and developed powerful techniques, based on the principle of reinforcement (reward). The methods of operant conditioning led to new discoveries such as reinforcement schedules and to considerable advances in our understanding of how reward and punishment affect not just rats and pigeons but human beings. Almost all his experiments were with animals because they could be raised and tested in a controlled environment so that the causes of the measured behavior could be identified with certainty, something that is simply not possible with human subjects. (Lemov writes, “They chose rats because they considered them close enough to humans to be representative but not close enough to be disturbing." In fact most Skinnerian behaviorists worked with pigeons rather than rats-and not because they preferred feathers to fur.)

Skinner had little interest in behavioral biology and did indeed consider his pigeons as models for humans, although it is a gross exaggeration to say, as Lemov says of Watson, "the activities of animals under experimental conditions were equivalent to human activities under all conditions." But many of his followers as well as Hull's looked at pigeons and rats as systems from which laws and processes might be inferred that might then have some human applicability. A better analogy would be the step from studying simple inorganic chemistry to the much more complex chemistry of organic compounds. No one expected salt to be a model for a protein, but much could be learned about

7 Edwin G. Boring, A History of Experimental Psychology, 2nd edition (Appleton-Century Crofts, 1929/1950); Sensation and Perception in the History of Experimental Psychology (Appleton-Century Crofts, 1942).

8 Skinner's dissertation was on The concept of the reflex in the description of behavior (1930), with physiologist William Crozier. 
proteins by first studying salts. It is simply not true that "[behavioral] scientists willingly modeled human society on rat behavior in . . . a bald-faced way." (In fact modern medicine is probably more guilty than behavioristic psychology of taking “animal models” literally.)

Lemov's book has a few errors which suggest serious limitations on the author's grasp of basic science. For example, writing about an experiment of Hull's she writes: “current ranged in intensity from 3.3 amperes to 7.6 volts ..." which is like saying "the samples weighed from three pounds to four inches." She speaks dismissively of early research on "the curious abilities of certain talented cats or foot-stomping horses." Perhaps she is referring to the famous “Clever Hans” experiment which showed that a circus-trick horse that seemed to count and add was in fact responding to unconscious cues from its trainer, a far-from-trivial piece of detective work.

In a particularly egregious passage Lemov writes "the coauthor of the famous Bell Curve, Richard Herrnstein, who trained as a behaviorist at Harvard, could not have made his controversial argument about how race in human beings is linked to IQ without doing extensive work on pigeon behavior in the laboratory.” I worked in Herrnstein's pigeon lab ${ }^{9}$ from 1962-64, and I can say without equivocation that this is absolute nonsense. Herrnstein was Skinner's student. IQ is part of the study of individual differences. Skinner's message was the essential uniformity of humans-and animals. A famous picture of his ${ }^{10}$ shows the performance on what is called a multiple schedule, in which successive stimuli signal payoff according (in these data) either to time or number of responses. Each stimulus evokes a distinctive pattern in a trained subject. The three graphs in the picture show essentially identical records from individuals from three species: pigeon, monkey, and human, on the same complex reinforcement schedule. Skinner comments “the curves are quite similar.” Yes, they are and the essential uniformity of adaptation to reinforcement schedules was a major theme of Skinner's work as well as Herrnstein's at that time.

Skinner's chief interest in individual differences was to find ways to minimize them. Herrnstein's later interest in individual differences, in connection

9 Lemov might have consulted a special issue of The Journal of the Experimental Analysis of Behavior (May 2002) 77, no. 3: 211-392, devoted to reminiscences about the Skinner-Herrnstein pigeon lab at Harvard, to get a more accurate idea of the atmosphere in which Herrnstein worked.

10 B. F. Skinner, "A case history in scientific method.," American Psychologist 11, no. 5, (May, 1956): 221-233, Figure 14. 
with IQ and crime, has no discernible connection to his work on the operant conditioning of pigeons.

Herrnstein's first essay into Bell Curve territory of which I am aware was a long article in The Atlantic Monthly and a book I.Q. in the Meritocracy, both published in 1971. A more likely source of Herrnstein's interest is not Skinner or pigeons, but a Memorial Hall zeitgeist dominated by psychophysicist S.S. “Smitty” Stevens (1906-1973). Smitty had a side interest in somatotyping, the flawed attempt by W. H. Sheldon to assess personality by three measurements of body type. There was some casual discussion of body type and IQ in the basement of Mem Hall at that time; it was never a theme in any lab, as far as I am aware.

World as Laboratory is an embarrassment given its provenance and the popularity of the topics it covers. It parodies behavioral science which is not (as one reviewer put it) "the theory that there is a predictable pattern between stimulus and response in the human brain.” Many, if not all, behaviorists were looking for the process that mediates between stimulus and response, not some magical omnipotent stimulus. Indeed, this is the aim of all scientific psychology, although schools differ on what processes are important. The book elides the context of behavioral psychology and betrays some ignorance of basic science as well as a skimpy knowledge of experimental and comparative psychology. It is only partially successful as a work of journalism; as a work of scholarship it fails badly.

History of science is important because it tells non-scientists, and would-be scientists, what science is. If historians of science present a distorted picture, they imperil the future of science, a future on which modern civilization depends. Professor Lemov's errors are not just "academic.” 